\title{
APPAREL SHOPPING BEHAVIOUR - PART 1: TOWARDS THE DEVELOPMENT OF A CONCEPTUAL THEORETICAL MODEL
}

\author{
R DU PREEZ \\ Department of Industrial Psychology \\ University of Stellenbosch
}

\begin{abstract}
Apparel shopping behaviour in a multicultural society is a complex phenomenon. The objective of this paper is to analyse various theoretical models from two disciplines, namely Consumer Behaviour and Clothing, and to develop a new conceptual theoretical model focussing on variables influencing apparel shopping behaviour in a multicultural consumer society. Variables were presented as market dominated, consumer dominated, and/or market and consumer interaction variables. Retailers, marketers, educators, researchers and students could benefit from the proposed model and recommendations are made in this regard. Part 2 reports on an empirical study based on the proposed conceptual theoretical model and discusses market segments and profiles.
\end{abstract}

\section{OPSOMMING}

Klere-aankoopgedrag in 'n multi-kulturele verbruikersamelewing is 'n komplekse fenomeen. Die doelwit van die artikel is om verskeie teoretiese modelle vanuit twee dissiplines, naamlik Verbruikersielkunde en Kleding, te analiseer. 'n Nuwe konseptuele teoretiese model is ontwikkel. Die model fokus op veranderlikes wat klereaankoopgedrag in 'n multi-kulturele verbruikersamelewing beinvloed. Veranderlikes word gegroepeer op grond van die mate waartoe dit oorheers word deur die mark, verbruiker en/of die interaksie tussen die mark en die verbruiker. Kleinhandelaars, bemarkers, opvoeders, navorsers en studente sou kon voordeel trek uit die voorgestelde model. Aanbevelings word in dié verband gemaak. In Deel 2 word 'n empiriese studie gerapporteer. Dié studie is op hierdie voorgestelde konseptuele teoretiese model gegrond en marksegmente sowel as profiele word bespreek.

Consumers will drive the market in the $21^{\text {st }}$ century. They exert their spending power within a marketplace, thereby influencing the success of all stakeholders in that marketplace. It is therefore crucial that manufacturers, retailers and marketers understand consumers in order to survive and be profitable in the highly competitive and rapidly changing $21^{\text {st }}$ century. This study aims to incorporate the fields of Consumer Behaviour and Clothing in order to gain knowledge on the variables influencing apparel shopping behaviour in a multicultural consumer society.

The research problem that directed this investigation was: What are the variables influencing apparel shopping behaviour within a multicultural consumer society?

Apparel shopping behaviour is not the result of a single variable, but rather a phenomenon that is influenced by a very large number of variables. Some variables can be classified as conscious and others as subconscious, some as market dominated and others as consumer dominated, and some as a fusion of the two, thus increasing the complexity thereof. The apparel consumer must be studied in his/her own right, as the decisions regarding apparel are not similar to decision-making with regard to other products (De Klerk, 1999; Du Plessis \& Rousseau, 1999).

Various consumer decision-making models (Engel, Blackwell \& Miniard, 1995; Schiffman \& Kanuk, 2000), as well as consumer behaviour models with an apparel perspective (De Klerk, 1999; Eckman, Damhorst \& Kadolph, 1990; Sproles, 1979), have been documented in the past. These models will be used as a point of departure, as no integrated apparel shopping behaviour model that emphasises process variables could be identified for the South African apparel consumer in a multicultural society. This study is further motivated by the gap in knowledge of apparel shopping behaviour in South Africa and the necessity for manufacturers, retailers, marketers and researchers to gain scientific knowledge regarding variables influencing apparel shopping behaviour.

Apparel shopping behaviour will be analysed and reported in two papers. Part one will focus on the development of a conceptual

Requests for copies should be addressed to: $R$ du Preez, Department of Industrial Psychology, University of Stellenbosch, Private Bag X1, Matieland, 7602 theoretical model regarding the variables impacting on apparel shopping behaviour in a multicultural consumer society. Part two will report the empirical validation of selected variables from the macro-conceptual theoretical model. Profiles of the different market segments and implications for manufacturers, marketers, retailers and academia will be discussed.

\section{MOTIVATION FOR BUILDING THEORETICAL MODELS}

The need for a theoretical base for research and the importance of contributing to theory building in the fields of Consumer Behaviour and Clothing have been emphasised by several practitioners. De Klerk (1999), Damhorst (1991) and Shim (1998) stated that researchers should place issues and concepts in the context of a theoretical framework in order to contribute to the understanding of markets, consumers and marketing dynamics. The renewed interest of consumer behaviourists in theory development and a scientific approach to the testing of theory has been emphasised by several researchers (Cowles \& Crosby, 1986; Eckman et al., 1990; Nagasawa, Kaiser \& Hutton, 1989).

Damhorst (1991) is of the opinion that models and theories are equally important to scientific progress. Theory development becomes haphazard and inefficient without models of the process or system under investigation. Theory is a set of related or internally consistent propositions that explain, interpret, describe and/or predict a phenomenon in a highly simplified manner in order to be applied to a large number of phenomena (Damhorst, 1991; Winakor, 1988). A model is also a set of internally consistent propositions that map out the components of a system or process. Relationships among the components are indicated and are usually presented visually. Models serve as maps of what makes up a specific phenomenon, whereas theories explain why and how the parts of a system or process interact and function in the manner they do (Damhorst, 1991; Engel \& Blackwell, 1982; Loudon \& Della Bitta, 1993).

Several benefits are associated with theory development. Firstly, the development of theory highlights areas of empirical research that have previously been neglected. 
Secondly, it provides a common vocabulary and framework that could improve communication between researchers and practitioners. A third benefit is that of delimitation, whereby the researcher can more successfully limit the scope of attempted research and can contribute to theory building in a specific manner. Fourthly, the understanding of the theoretical underpinnings of the marketplace and consumer behaviour can be strengthened. Lastly, theory development will encourage deductive research that is more theory driven. This will increase the cost-benefit ratio of doing empirical research and indicates the development of a discipline (Engel \& Blackwell, 1982; Sheth, 1983; Shim, 1998).

Assael (1992) and Engel et al. (1995) emphasised the importance of using a consumer behaviour model that describes the sequence of factors that leads to purchase behaviour. Motivation for this can be found in the following: Models encourage a total and integrative view of consumer behaviour. It would be irresponsible for stakeholders to attempt to understand the purchasing behaviour of their clientele without having a holistic framework of variables that could influence consumer behaviour. The quantification of the variables and their relationships is encouraged in a statistically reliable manner. Models also provide a basis for the development and evaluation of marketing strategies, as well as for market segmentation. The application of models identifies/ascertains/exposes gaps in knowledge and facilitates the identification of research priorities.

The usefulness of consumer models in marketing management is, however, hampered by four limitations (Assael, 1992). Model components may not be equally important or relevant to all product categories. All the components of a general model of consumer behaviour may not be equally important for all usage situations. No two individuals are the same, as they differ with regard to the variables of the model. This results in model components having different values, weights and importance for individuals in the same market. All purchase decisions are not equally complex. The complexity of the decision-making process will, for example, impact on consumers' degree of information search, as well as evaluation of alternatives and choice of products from the evoked set.

These limitations should not restrict the use of decision-making models. Models may differ, for example, with regard to complexity and consumer involvement. The degree of involvement in the decision-making process depends more on the individual's attitude towards the product than on the product characteristics itself (Du Plessis \& Rousseau, 1999). Some individuals are highly involved when purchasing apparel items, while others may experience it as a routine process. A general model for apparel shopping behaviour should therefore make provision for these varying levels of involvement.

Several researchers (Durvasula, Lysonski \& Andrews, 1993; Visser \& Du Preez, 1998; Visser, Du Preez \& Du Toit, 1996) have emphasised that data and models that were developed in the United States cannot be accepted as valid in other countries. This issue is addressed in the present research project by using universal consumer behaviour models and applying them to a South African context.

Why then is it necessary to develop a new conceptual model for apparel consumer behaviour if some models already exist? One of the major reasons is that the existing models lack the comprehensiveness (for example De Klerk, 1999; Eckman et al., 1990; Schiffman \& Kanuk, 2000) to identify the majority of the variables affecting the purchase decision-making process for apparel products. These models focus on the decision-making process, rather than on the variables moderating or influencing the process. However, these models can contribute to the understanding and approach to building a theoretical model. Another reason is that no existing integrated model of apparel shopping behaviour could be identified for the South African apparel consumer. It should also be stated that interdisciplinary research on apparel consumer behaviour is limited in South Africa. Consequently, theoretical models encompassing variables relevant to the different disciplines do not exist.

\section{OBJECTIVES FOR DEVELOPING A MACRO- CONCEPTUAL THEORETICAL MODEL}

Developing the conceptual theoretical model aims to:

- be as inclusive as possible and to assist researchers in identifying possible variables that influence apparel shopping behaviour;

- encourage an integrative and multidisciplinary view of variables influencing apparel shopping behaviour;

- assert that apparel shopping behaviour is not a simple phenomenon, but rather is a complex process with numerous variables influencing the outcome thereof;

- contribute to theory building in the fields of Consumer Behaviour and Clothing.

\section{METHODOLOGY}

The following theoretical models of Consumer Behaviour and Clothing were studied and served as the point of departure for developing the comprehensive conceptual theoretical model:

- The Consumer's Fashion Adoption Process - A General Model (Sproles, 1979). This model is widely accepted in the clothing field as a general, very inclusive model for fashion adoption (hereafter referred to as the Sproles Model).

- The Engel-Blackwell-Miniard Model of Consumer DecisionProcess Behaviour (EBM Model) (Engel et al., 1995). The EBM Model is widely regarded as a comprehensive model of consumer decision-making in the field of Consumer Behaviour.

- The Clothing Consumer Decision-Making Model (De Klerk, 1999). This is a model developed in South African and is apparel related.

- Model of In-Store Apparel Purchase Decision Process (Eckman et al., 1990). This simplified model focusses on the three stages of the in-store decision-making process, viz. interest, trial, and buying or rejecting.

- The Simple Model of Consumer Decision-Making (Schiffman \& Kanuk, 2000). This model combines numerous variables in the three stages of decision-making, viz. input, process and output.

The first three models (the Sproles Model, the EBM Model and De Klerk's Clothing Consumer Decision-Making Model) are widely accepted to form the basis of the proposed conceptual theoretical model. Information gained from other models, such as Darden's Model (Darden, Erdem \& Darden, 1983), the Model of Adult Purchase Decision-Making Process for Furniture (Du Plessis \& Rousseau, 1999), the Howard-Sheth Model of Buyer Behaviour and the Sheth Family Decision-Making Model (Schiffman \& Kanuk, 1987) were incorporated in the development of a new conceptual model.

\section{RESULTS: MACRO-CONCEPTUAL THEORETICAL MODEL}

The model is largely self-explanatory. The variables in the model are categorised into three groups, viz. market-dominated variables, consumer-dominated variables and variables pertaining to both market and consumer interaction, when it cannot be said that either the consumer or the market is dominant. These variables, in turn, influence the consumer decision-making process that results in specific apparel shopping behaviour. The macro-conceptual model was not 


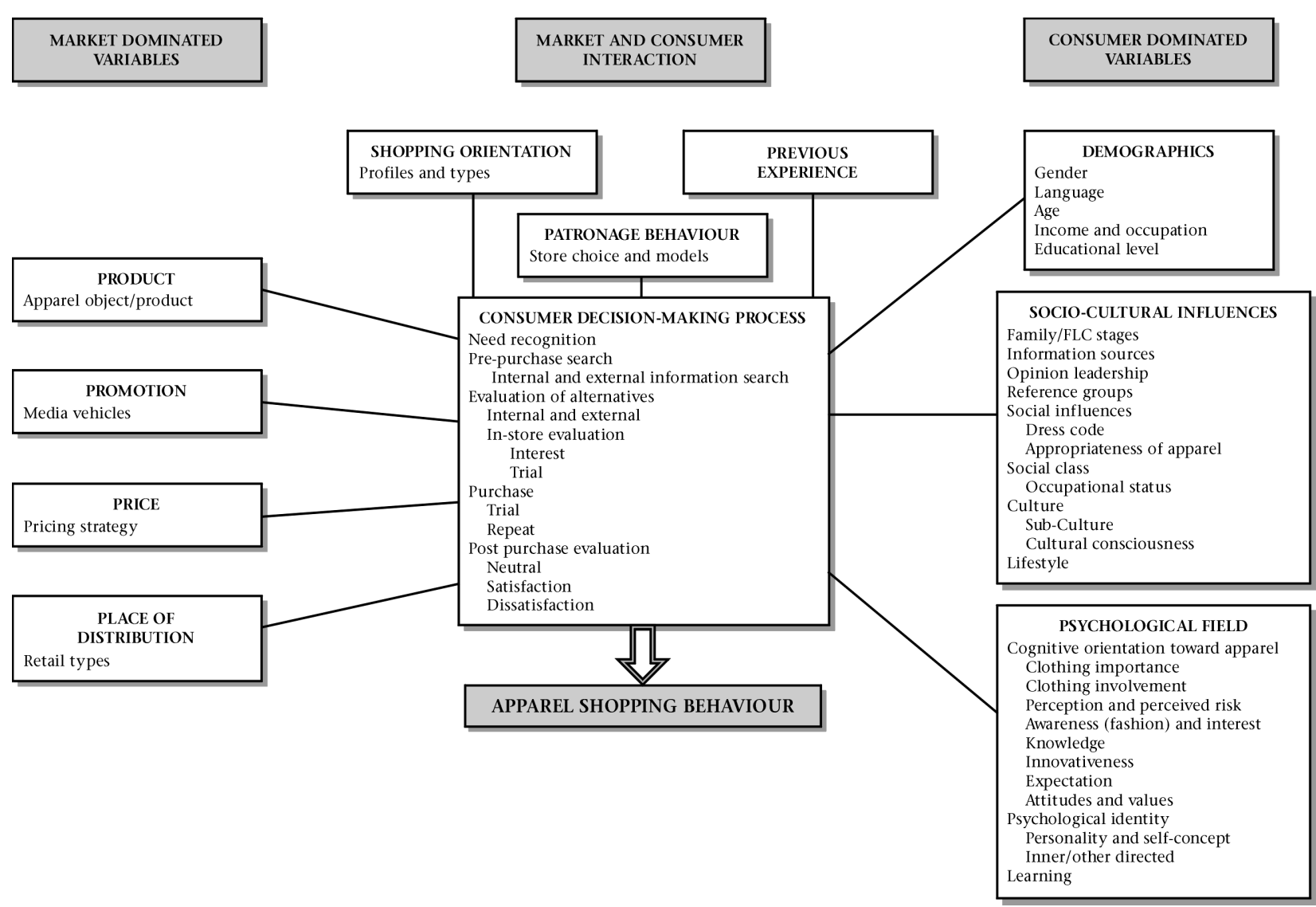

Figure 1: Conceptual theoretical model: a macro-perspective of variables influencing apparel shopping behaviour

developed to be a predictive model or to be a model showing all the relationships between different variables that could influence apparel shopping behaviour. This proposed conceptual theoretical model is congruent with Assael's (1992) proposition that consumer behaviour models should describe the sequence of factors that lead to purchase behaviour.

\section{CONCLUDING REMARKS}

No retailer would be able to influence shopping behaviour without an understanding of the variables that influence behaviour. The proposed conceptual model provides apparel marketers with a holistic scientific view of variables influencing apparel shopping, thus assisting in the development of strategic marketing plans. The use of the model could enhance the understanding of apparel consumer behaviour, as it takes cognisance of key variables that influence buying behaviour. Marketers who know why consumers purchase or do not purchase apparel will succeed in communicating with them. Demographics, socio-cultural influences, such as family, lifestyle and culture, patronage behaviour, shopping orientation, the product and the place of distribution are some of the variables that impact on the consumer decision-making process and result in apparel shopping behaviour. However, many other variables can also be identified and investigated.

Any research should hold implications for academia. Educators in the field of Clothing could benefit from the development of the macro-perspective model in various ways. The model provides a conceptual framework for developing course curricula, especially in Consumer Behaviour. The model could also be used in assessment. Students should have a thorough knowledge of all the components of the macro-perspective model after completion of a course that provides holistic knowledge of Consumer Behaviour, as applied to Clothing, as an outcome. Most students find it difficult to visualise, understand and apply knowledge gained in one field of study (e.g. Clothing) to another, such as Consumer Behaviour. They may benefit from their knowledge and understanding of the numerous variables that influence apparel shopping behaviour in a multicultural consumer society. This interdisciplinary model would simplify the process of grasping the meaning of the constructs and their multidimensionality. This might encourage interdisciplinary studies that focus on the relationships between the variables.

The model could be used as a point of departure for future research. It will assist in the delineation of studies and could contribute to the development of new models and theory. The conceptual model can further assist researchers to identify gaps in the knowledge and understanding of consumer behaviour. Applying the macro-perspective model can thus facilitate new research initiatives and priorities.

Conceptual theoretical models have limitations. Firstly, the relationships between the various variables are not proposed and tested empirically. Secondly, the models lack prediction value. The macro-conceptual theoretical model should be tested and refined. Part two of the paper will report on an attempt to address these issues by selecting various variables from the macro-conceptual theoretical model, assessing their influence on apparel shopping behaviour and segmenting the market accordingly.

\section{REFERENCES}

Assael, H. (1992). Consumer behavior and marketing action. (4 ${ }^{\text {th }}$ ed.). Boston: PWA-Kent.

Cowles, D. \& Crosby, L.A. (1986). Measure validation in consumer research: a confirmatory factor analysis of the voluntary simplicity lifestyle scale. Advances in Consumer Research, 13, 392-397 
Damhorst, M.L. (1991). Relation of textiles and clothing research to scientific inquiry in social cognition. ITAA Special Publication 4, 191-202. Monument: ITAA.

De Klerk, H.M. (1999). 'n Sosiaal-sielkundige en kognitiewe benadering tot die ontwikkeling van 'n kledingverbruikersbesluitnemingsmodel (A social psychology and cognitive approach to the development of a clothing consumer decision-making model). Journal of Family Ecology and Consumer Sciences, 27 (2), 116-128.

Darden, W.R., Erdem, O. \& Darden, D.K. (1983). A comparison and test of three causal models of patronage intentions. In W.R. Darden \& R.F. Lusch (Eds.), Patronage Behaviour and Retail Management. New York: North-Holland.

Du Plessis, P.J. \& Rousseau, G.G. (1999). Buyer behavior. a multicultural approach. (2nd ed.) Halfway House: International Thompson Publishing.

Durvasula, S., Lysonski, S. \& Andrews, J.C. (1993). Crosscultural generalizability of a scale for profiling consumers' decision-making styles. Journal of Consumer Affairs, 27 (1), 55-65.

Eckman, M., Damhorst, M.L. \& Kadolph, S.J. (1990). Toward a model of in-store purchase decision process: consumer use of criteria for evaluating women's apparel. Clothing and Textiles Research Journal, 8 (2), 13-22.

Engel, J.F. \& Blackwell, R.D. (Eds.) (1982). Consumer behavior. ( $4^{\text {th }}$ ed). New York: The Dryden Press.

Engel, J.F., Blackwell, R.D. \& Miniard, P.W. (1995). Consumer behaviour. ( $8^{\text {th }}$ ed.). New York: The Dryden Press.
Loudon,D.L. \& Della Bitta, A.J. (1993). Consumer behavior: concepts and applications. (4th ed.). New York: McGraw Hill.

Nagasawa, R.H., Kaiser, S.B. \& Hutton, S.S. (1989). Theoretical development in clothing and textiles: are we stuck in the concrete? Clothing and Textiles Research Journal, 7 (2), 23-31.

Schiffman, L.G. \& Kanuk, L.L. (1987). Consumer behavior. (3rd ed.). New Jersey: Prentice Hall.

Schiffman, L.G. \& Kanuk, L.L. (2000). Consumer behavior. (7th ed.). New Jersey: Prentice Hall.

Sheth, J.N. (1983). An integrative theory of patronage preference and behavior. In W.R. Darden \& R.F. Lusch (Eds.), Patronage Behaviour and Retail Management. New York: North-Holland.

Shim, S. (1998). The changing marketplace in the global economy: implications for future research. Family and Consumer Sciences Research Journal, 26 (4), 444-461.

Sproles, G.B. (1979). Fashion: consumer behavior toward dress. Minnesota: Burgess.

Visser, E.M. \& Du Preez, R. (1998). Consumer behaviour of mature female apparel shoppers: a cultural perspective. In N.J. Miller \& M.A. Littrell (Eds.), International Apparel Consumer Behavior. A Collection of Readings and Course Activities. (pp. 41-51). Iowa: Iowa State University.

Visser, E.M., Du Preez, R. \& Du Toit, J.B. (1996). The mature female clothing shopper: profiles and shopping behaviour. Journal of Industrial Psychology, 22 (2), 1-6.

Winakor, G. (1988). Research in fashion merchandising - the need for a theoretical base. Clothing and Textiles Research Journal, 7 (1), 31-35. 